\title{
Forest trees at Kamalpur, Patamda valued for anticarcinogenic effects
}

\author{
SHILA KUMARI GOPE* AND GEETA
}

Jamshedpur Women's College, JAMSHEDPUR (JHARKHAND) INDIA

\section{ARITCLE INFO}

Received : 03.01 .2015

Accepted : 18.03.2015

\section{KEY WORDS :}

Antiproliferative, Anticarcinogenic, Antioxidant, Ethnomedicine

*Corresponding author:

Email: Shilagope75@gmail.com

\begin{abstract}
This paper has been an attempt to gather data on certain trees present in a small forest patch of Singhbhum at Patamda block for anticarcinogenic and antiproliferative activities co-operation from different tribal and rural people helped identifying the trees along with their local usage. These usage were compared and revaluated with the published records on medicinal plants. Such trees are enlisted in this effort with their botanical name, families and local names. These trees should be conserved to promote development of bioactive molecules in future by creating awareness in local people.
\end{abstract}

How to view point the article : Gope, Shila Kumari and Geeta (2015). Forest trees at Kamalpur, Patamda valued for anticarcinogenic effects. Internat. J. Plant Protec., 8(1) : 199-203. 